\title{
Profile Enhancement Students' Critical Thinking Skills of 7th Grade Junior High School in Natural Science Learning with Environmental Polution Subject Assisted by PODE worksheet
}

\author{
${ }^{1}$ Imega Syahlita Dewi, ${ }^{2}$ Rina Puji Utami \\ Department of Science Education, Faculty of Teacher Training and Education, STKIP PGRI \\ Nganjuk $^{1}$. Department of English Education, Faculty of Teacher Training and Education, \\ STKIP PGRI Nganjuk². Jln. Abdul Rahman Saleh No. 21 Nganjuk, Jawa Timur 64411 \\ Email: imegasyahlita@stkipnganjuk.ac.id
}

\author{
Article Info \\ Article History \\ Received: 05 Agustus 2019 \\ Revised: 13 September \\ 2019 \\ Published: 30 September \\ 2019 \\ Keywords \\ Critical Thinking Skill, \\ PODE Worksheet, Natural \\ Science Learning, One \\ Shot Case Study
}

\begin{abstract}
This research describes the profile of improving critical thinking skills of class VII.3 students at SMPN 4 Nganjuk in natural science learning of environmental pollution subject with the help of PODE worksheet (Predict, Observe, Discuss, Explain). Indicators of critical thinking skills assessed in this research those are: 1) Interpretation, 2) Analysis, 3) Explanation, 4) Inference, 5) Evaluation and 6) Self Regulation. The six indicators of critical thinking skill can be trained through the activities presented in the PODE worksheet. This type of research is Classroom Action Research. The method used is a pre-experimental design type One Shot Case Study, meaning that there is a group given treatment then the results are observed. The initial profile of students' critical thinking skills before using PODE worksheet shows an unfavorable category with an average overall percentage of $40.88 \%$. Furthermore, students' critical thinking skills experience improvement after being given PODE worksheet which contains learning activities to train students' critical thinking through many of problems in everyday life using successive steps starting from: Students predict problems, Students make observations with experiments, Students analyze the results of the experiment through discussion activities, and the last students explained by presentation. This is evidenced by the average acquisition of an overall percentage of $70.05 \%$ which shows a fairly good category. Thus it can be concluded that the profile of students' critical thinking skill has increased with the help of PODE worksheet.
\end{abstract}

Sitasi: Syahlita Dewi, Imega. Rina Puji Utami. (2019). Profile Enhancement Students' Critical Thinking Skills of 7th Grade Junior High School in Natural Science Learning with Environmental Polution Subject Assisted by PODE worksheet. Science Education and Application Journal (SEAJ). Vol. 1 No. 2: 56 - 61

\section{PENDAHULUAN}

Science learning in the $21^{\text {st }}$ century is characterized by achievement of abilities, especially in aspects of critical thinking. Critical thinking skill is a thinking model about problems to improve the quality of thinking by handling skillfully and establishing intellectual standards used to solve problems (Fisher, 2009). Indicator of critical thinking skill according to Fascione consists of: Interpretation, analysis, explanation, inference, evaluation, and selfregulation (Fascione, 2015). The profile of students' critical thinking skills in certain regions in Indonesia can be categorized as low, this is evidenced by the existence of: 1) Research conducted by Purwanto in 2012 shows a profile of students' critical thinking skills in Sumedang Regency are still low which is only 24, $2 \%$ (Purwanto, et al. 2012); 2) The results of Hendrik's research in 2016 study explain the critical thinking skills of Grade VIII students of SMP N 7 Pasuruan are still relatively low, because students who fulfill each indicator of critical thinking 
ability are still below 50\% (Hendrik, et al. 2016); 3) Research conducted by Icha in 2018 can be concluded that students with low critical thinking skills are only able to focus on things that are known and asked only, in addition students can only mention the previous material related to solving the problem without solving the problem (Icha Shofia, et al. 2018). Based on the profile data of students' critical thinking skill in Indonesia, the problem is very important to immediately find a solution so that it can help improve students' critical thinking skill.

The problem about the low critical thinking skill mentioned above has the suitability of conditions in class VII.3 of SMPN 4 Nganjuk, East Java. The results of the observations showed that there were several problems in students' critical thinking skill in accordance with the indicators of critical thinking according to Fascione, among others: First, students were still unable to answer the questions given by the teacher at the beginning of learning. Second, when giving answers to questions or opinions of friends, students have not been able to analyze problems and provide solutions, this is an indicator of students' ability to analyze is still low. Third, students have difficulty in answering differences, this is an indicator of the ability to evaluate students still lacking because they have not been able to compare and determine what is the differentiator based on the standards specified. Fourth, the ability to refer students is still low, it is seen when students conclude the results of observational or experimental data. Fifth, students' ability to explain is still low, because students have not been able to provide explanations of questions that require analysis, this can be seen from the way students answer questions still single and disconnected. Sixth, students have not been accustomed to evaluating their own knowledge related to problems or phenomena that exist, this shows that students' self-regulation ability is still low.

Teachers are considered to be at the forefront of the education process because who apply the curriculum and facilitate student learning (Joan, 2019). Achievement of critical thinking skill can be done through improving the quality of learning by teachers design learning into student center learning in accordance with phenomena and problems in everyday life, so as to help students improve critical thinking skill, encourage cooperation and communication, increase involvement and activity students. Critical thinking skill is one part of HOTS (High Order Thinking Skill) that students can use to complete learning activities and help students in following the learning process (Conklin, W. 2012 ). The basis of HOTS assessment in this case is that critical thinking skill can be done by giving tasks that encourage the use of knowledge and skills in different conditions for each student (Brookhart, S.M. 2010). Efforts that need to be done so that this can be done is to make improvements to the learning media that are appropriate to the needs of students so that it can facilitate communication between students or students and teachers.

Learning media that allow it to be used are Student worksheets (LKS), which are sheets that contain guidelines to facilitate students in conducting learning activities during observations and experiments. Worksheet are usually in the form of instructions and steps to complete a task (Devi, et al. 2009). Worksheet is a form of learning guide used in learning that functions as a student learning guide and can also facilitate students and teachers more easily during the learning process (Susilowati. 2013). Worksheet is one part of the learning device. Worksheet in accordance with the 2013 curriculum are worksheets that can improve students' critical thinking skill and activeness, one of which is PODE worksheet (Predict, Observe, Discuss, Explain). It's expected to encourage active students during the learning process and make each student think critically to construct their own knowledge and also students can communicate their thoughts and then write them in their own language so that they are easy to understand and make students understand concepts properly and correctly (Retnosari, et al. 2018 ), thus expected with the help of PODE worksheet can help to improve students' critical thinking skill. 


\section{METODE}

The research method are uses a pre-experimental design type One-Shot Case Study. The paradigm in the research of this model is described as follows:

$$
\begin{array}{l|l}
\mathrm{XO} & \begin{array}{l}
\mathrm{X}=\text { Treatment given } \\
\mathrm{O}=\text { Observation }
\end{array}
\end{array}
$$

It's mean there is a group given treatment then the results are observed. Treatment is an independent variable and the result is the dependent variable (Sugiyono. 2011). The data analysis technique used is descriptive qualitative percentage, this is used to determine the average process of improving students' critical thinking skill at each stage of the research conducted. Indicators of critical thinking skill assessed in this research are: 1) Interpretation, 2) Analysis, 3) Explanation, 4) Inference, 5) Evaluation and 6) Self- Regulation. Improvement of critical thinking skill in each cycle can be used as an indicator that students' understanding of PODE worksheet is good so that students' critical thinking skills can be improved, equations and criteria for critical thinking assessment scores are used (Prastowo. 2014):

$$
\mathrm{P}=\frac{\sum \mathrm{ni}}{\mathrm{N}} \mathrm{X} 100 \%
$$

$\mathrm{P} \quad=$ Percentage of scores obtained

$\sum$ ni $\quad$ Number of scores obtained

$\sum \mathrm{n} \quad=$ Maximum number of scores

TABLE 1. The assessment of critical thinking skill's category

\begin{tabular}{|l|l|}
\hline \multicolumn{1}{|c|}{ Score } & \multicolumn{1}{c|}{ Criteria } \\
\hline $90 \%-100 \%$ & Very Good \\
\hline $80 \%-89 \%$ & Good \\
\hline $70 \%-79 \%$ & Fairly Good \\
\hline$<70 \%$ & Unfavorable/ Bad \\
\hline
\end{tabular}

\section{HASIL DAN PEMBAHASAN}

The initial profile of students' critical thinking skill before using the PODE WORKSHEET(pre-cycle) shows an unfavorable/ bad category with an average overall percentage of $40.88 \%$ with details per indicator as follows: 1) Interpretation: $43.75 \%, 2$ ) Analysis 37, 5\%, 3) Explanation 41.40\%, 4) Inference 42.18\%, 5) Evaluation of $42.96 \%$, and 6) Self Regulation: $37.5 \%$. Furthermore, the profile of students' critical thinking skill has increased after being given the PODE worksheet which contains learning activities to train students' critical thinking through the problems in everyday life using successive steps starting from: 1) Students predict problems, 2) Students make observations with experiments, 3) Students analyze the results of the experiment through discussion activities, and the last 4) Students explain by presentation. This is evidenced by the average acquisition of an overall percentage of $70.05 \%$ which shows a fairly good category with details per indicator as follows: 1) Interpretation: $68.75 \%, 2$ ) Analysis $70.31 \%$, 3) Explanation $67.18 \%$, 4) Inference of $72.65 \%, 5)$ Evaluation of $69.53 \%$, and 6) Self regulation: $71.87 \%$. The results of this research are in accordance with the results of a research conducted by Hasratuddin in 2008 which showed that the profile of students' critical thinking skill in Medan has increased, it can be 
seen from the results of an average increase in students' critical thinking skill of 10.62 from the average acquisition the initial score was only 0.88 to 11.50 (Hasratuddin. 2008). The description of the profile of thinking skills is more complete can be seen in the figure table below:

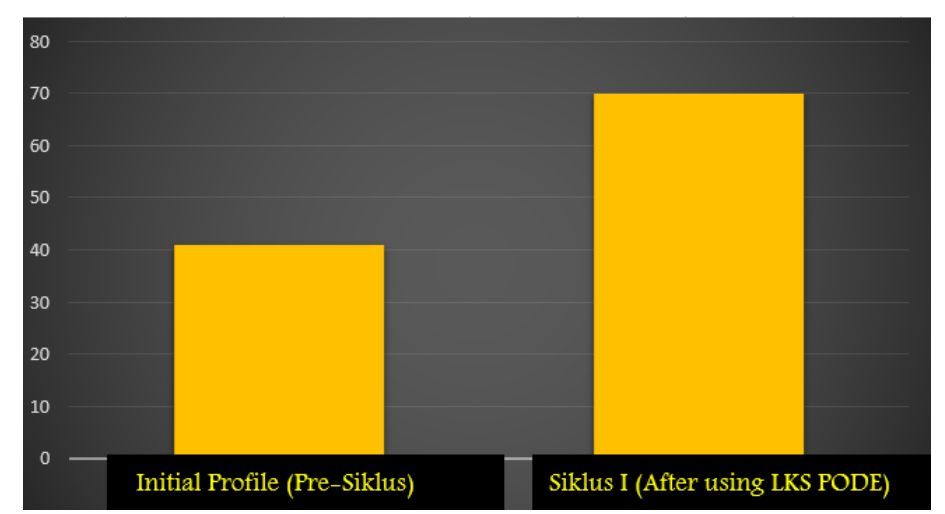

FIGURE.1 Profile Enhancement Students' Critical Thinking Skill

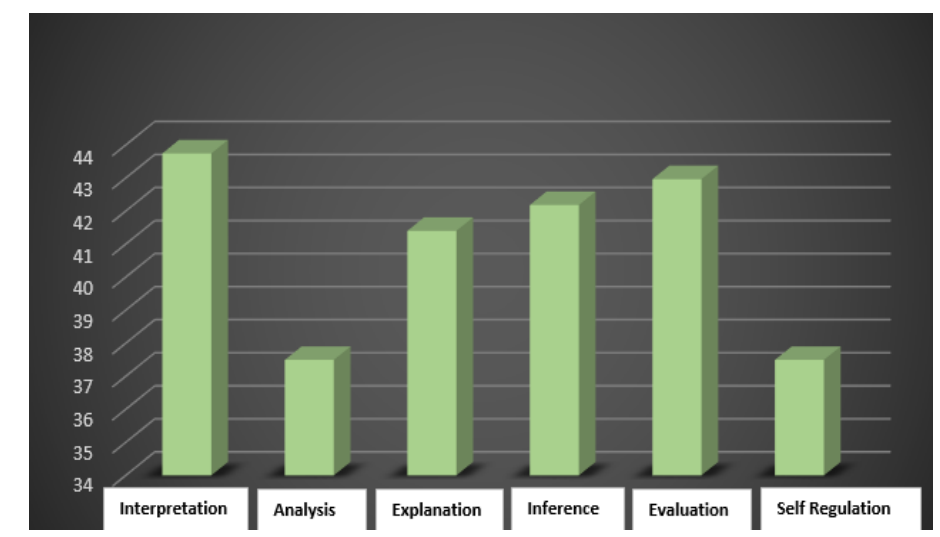

FIGURE.2 The initial profile Students' Critical Thinking Skill (before using PODE worksheet)

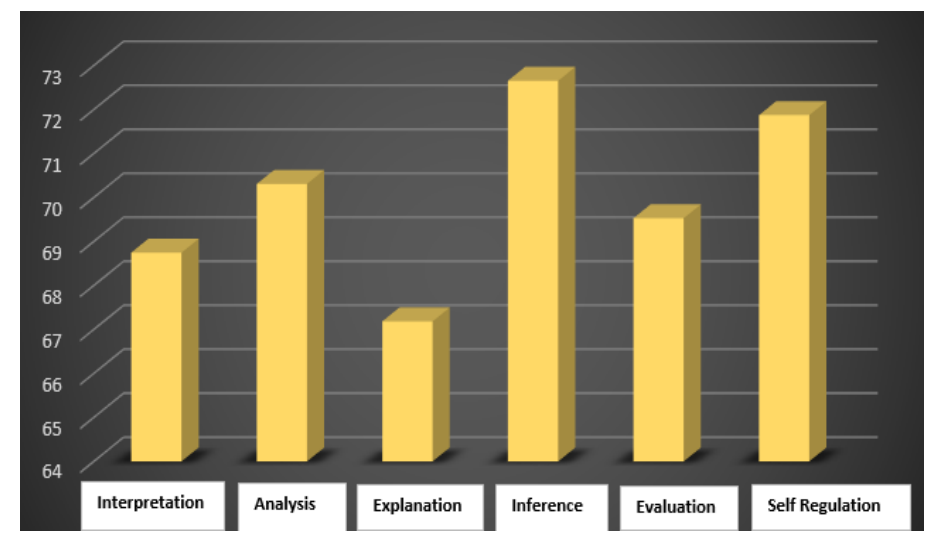

FIGURE.3 The profile Students' Critical Thinking Skill (after using PODE worksheet)

Critical thinking skill is one part of HOTS (High Order Thinking Skill) that students can use to complete learning activities and help students in following the learning process (Conklin, W. 2012). According to research by Yee Mei Heong in 2011, there was no significant difference in the level of thinking between male and female students, this was relevant to the results of this research which showed that students' critical thinking levels were not based on gender, but by how often students practice solving problems through the scientific method and the right steps. 
Based on four aspects in the PODE worksheet, those are: 1) Predict, students make guesses; 2) Observe, students make observations; 3) Discuss, students discuss the result of observations; 4) Explain, students do explanations in front of the class, it can encourage students to be active during the learning process and can help each student to think critically by constructing their own knowledge and students can communicate their thoughts and then write them in their own language so that they are easier to understand and make students understand the concepts properly and correctly. According to the results of the research conducted by Dwi Retnosari in 2018 which showed that the PODE worksheet can improve students' critical thinking skill in light subject, it's can be seen from the results of the recapitulation of pretest posttest calculated using the gain score of 0.42 in the medium category.

Activities in science learning using PODE worksheet are also train students to solve problems scientifically through the process of observing, asking, trying, associating and communicating. The steps are sequentially carried out according to the syntax contained in the PODE worksheet which is through the activities of predict, observe, discuss, and explain. Scientific approach is highly recommended in learning activities in the 2013 curriculum because it effectively improves learning outcomes and can train students to solve problems with the scientific method, this is in accordance with the results of research conducted by Christian Doabler in 2011 which showed that students' initial scores before using the scientific approach is 1.44 and has increased to 9.3. PODE worksheet contains activities of everyday phenomena problems and has a correlation with environmental pollution subject and requires a process of problem-based learning. This is consistent with research conducted by Oktay Kizkapan in 2017 which states that problem-based learning can contribute to science teachers to teach constructivist teaching strategies that are effective and meaningful.

\section{KESIMPULAN}

Based on the analysis, three main conclusions were taken. First, the initial profile of students' critical thinking skills is still low with a percentage of $40.88 \%$ with an unfavorable category before being given the PODE worksheet assistance but experiencing an increase to $70.05 \%$ with a fairly good category after being given assistance with LKS PODE. Second, the increase in students' critical thinking skill in self-regulation indicators experienced the highest increase of all indicators, which amounted to $34.37 \%$. The three conclusions as a whole showed that the PODE worksheet could help to improve students' critical thinking skill

\section{SARAN}

Based on the analysis suggested:

1. PODE worksheet can be used by teachers as additional teaching materials on science learning in junior high school.

2. After reading this research, teachers in junior high school can be inspired to make similar teaching materials to help improve students' critical thinking skill that are still low

3. Further research on how to describe the critical thinking skills of senior high school students in science learning using PODE worksheet.

\section{DAFTAR PUSTAKA (12pt)}

[1] Fisher, Alec. Berpikir Kritis: Sebuah Pengantar. Jakarta: Erlangga.

[2] Fascione, P.A. 2015. Critical Thinking: What It Is and Why I Counts. California: California Academic Press.

[3] Purwanto, et al. 2012. Implementasi Permainan Monopoli Fisika sebagai Media Pembelajaran dalam Pembelajaran Kooperatif Tipe TGT untuk Meningkatkan Prestasi Belajar dan Mengetahui Profil Kemampuan Berpikir Kritis Siswa SMP. 
Jurnal Pengajaran MIPA, Volume 17, Nomor 1, April 2012, halaman 69-76. Bandung: FMIPA, Universitas Pendidikan Indonesia.

[4] Hendrik, et al. 2016. Profil Berpikir Kritis Siswa SMP N 7 Pasuruan. Prosiding Semnas Pendidikan IPA Pascasarjana UM, Volume 1, 2016, ISBN: 978-602-9286-21-2.

[5] Icha Shofia, et al. 2018. Profil Berpikir Kritis Siswa dalam Menyelesaikan Soal Fungsi Komposisi Melalui Model Pembelajaran Kolaboratif. Jurnal Didaktik Matematika, Volume 5, No.1 , April 2018. ISSN 2355-4185 (p), 2548-8546 (e), DOI 10.24815/jdm.v5i1.9972.

[6] Joan, Palma. 2019. Students' Concerns and Issues on Teachers and Teaching. International Journal of Education and Research Vol. 7 No. 2 February 2019.

[7] Conklin, W. 2012. Higher order thinking skills to develop 21st century learners. Journal of Education and Practice 8, 108-121.

[8] Brookhart, S.M. 2010. How to assess higher order thinking skills in your classroom (ASCD, Alexandria, 12, 2010)

[9] Devi, et al. 2009. Pengembangan Perangkat Pembelajaran untuk Guru SMP. Jakarta: Pusat Pengembangan dan Pemberdayaan Pendidik dan Tenaga Kependidikan Ilmu Pengetahuan Alam (PPPPTK IPA) untuk Program Bermutu.

[10] Susilowati. 2013. Integrated Science Worksheet Pembelajaran IPA SMP dalam Kurikulum 2013. Makalah PPM Diklat Pengembangan Student Worksheet Integrated Science bagi Guru SMP/ MTs di Kabupaten Sleman. Yogyakarta: UNY.

[11] Dwi Retnosari, et al. 2018. LKS PODE (Predict, Observe, Discuss, Explain) untuk Meningkatkan Keterampilan Berpikir Kritis Siswa. Pensa E-Jurnal, Volume 06, Nomor 02, 2018, 360-365.

[12] Sugiyono. 2011. Metode Penelitian Kuantitatif Kualitatif dan R\&D. Bandung: Alfabeta.

[13] Prastowo. 2014. Pengembangan Bahan Ajar Tematik Tinjaun Teoritis dan Praktik. Jakarta: Kencana Prenadamedia Group.

[14] Hasratuddin. 2008. Meningkatkan Kemampuan Berpikir Kritis Siswa SMP Melalui Pendekatan Matematika Realistik. Medan: Universitas Medan.

[15] Yee Mei Heong, et al. 2011. The Level of Marzano Higher Order Thinking Skills among Technical Education Students. International Journal of Social Science and Humanity, Vol. 1, No. 2, July 2011.

[16] Christian Doabler. 2011. Using A Scientific Process for Curriculum Development and Formative Evaluation. International Journal SREE Fall 2011, Conference Abstract Templete Institut of Education Science.

[17] Oktay Kizkapan. 2017. The Effect of Project Based Learning on Seventh Grade Students'Academic Achievement. International Journal of Instruction Vol.10, No.1 e-ISSN: 1308-1470, p-ISSN: 1694-609X, pp 37-54. 